\title{
In Their Own Words - How do Students Relate Drama Pedagogy to their Learning in Curriculum Subjects?
}

\author{
CHAN, Yuk-lan Phoebe \\ Hong Kong Art School
}

In memory of Jean Rudduck (11/2/1937 to $28 / 3 / 2007)-$ a
pioneer of student voice research and practice

\begin{abstract}
The rationale for this study is that students' views on their own learning play an integral part in their educational journeys. Students' voice has been gaining recognition as a vehicle for cultivating ownership of learning, restoring classroom dialogue, and developing strategies for school improvement. These benefits echo the pedagogical purposes of drama education. This study examines how a group of primary students in Hong Kong relate drama pedagogy to their learning in two curriculum subjects - Chinese Language and General Studies. Working with a group of primary students introduced to drama as a medium of learning for the first time, the researcher seeks to find out what aspects of the drama programme is seen by the students as pertinent to their learning in these subjects. The students generally found the Process Drama units more closely related to the learning in General Studies than Chinese Language. Factors influencing their views include the learning focus of the Process Drama work, students' beliefs about learning in these two school subjects, and the pedagogical approaches previously adopted in their school.
\end{abstract}

Keywords: student voice, process drama, Chinese language, curriculum

\section{Notes on contributor}

Chan Yuk-lan Phoebe is Lecturer/Programme Coordinator (Drama Education) at the Hong Kong Art School, where she convenes a Master of Drama Education Programme co-organised with Griffith University, Australia. She has a Master's Degree in Drama in Education from the University of Central England, and is currently undertaking her PhD study with Griffith University. For more than 10 years, she has worked with theatre companies, schools, communities and Oxfam Hong Kong in stage performance, applied theatre and Theatre in Education, teacher development in the use of drama as pedagogy, research projects, as well as editing, translating and authoring publications. 


\section{Introduction}

In the past decade, a growing number of Hong Kong schools have become interested in introducing drama-based approaches to the teaching of curriculum subjects. The call for more innovative and humanistic pedagogies in educational reforms gives drama a growing recognition as a medium of teaching. More and more schools participate in initiatives to equip their teachers with skills and knowledge in using drama. Artist-inresidence models are often adopted to introduce the new pedagogy in a site-specific manner. The project discussed in this paper uses this approach. Collaborating with five drama teachers from the Hong Kong Art School, a local primary school implemented a one-year drama programme with Primary One to Four classes. Process Drama units were designed for and conducted with each class in the four grade levels. A subject integration approach was adopted to assimilate learning outcomes taken from both the Chinese Language and General Studies syllabi. The study examines how the students in the programme relate the drama pedagogy to their learning in the two school subjects. The research seeks to find out what aspects of the drama units are seen as connected to the curriculum subjects, and the factors underpinning the students' views.

The data is drawn from student focus group interviews following the drama units. The rationale for the study is that students are "experts on their own perceptions and experiences as learners' (Oldfather 1995, 131), that their views on their own learning play an integral part in their educational journeys. Such a notion is informed by the gaining recognition of students' voice as a means of enhancing engagement in learning, restoring dialogues amongst learners and educators, and contributing to school improvement and education reforms.

\section{Listening to student voices in drama education}

Since the early 1990s, there has been a growing literature that addresses the exclusion of student voices in discourses about learning and teaching (Oldfather 1995). Jean Rudduck, an early advocate of student voice research and practice, criticizes such exclusion as founded upon an outdated view of childhood which fails to acknowledge children's capacity to reflect on issues affecting their lives (Rudduck \& Flutter 2000). The field of student voice studies 'challenges dominant images of students as silent, passive recipients of what others define as education' (Cook-Sather 2006b, 362).

There is much common ground between student voice studies and drama education. Both share rationales that are based on more student-centred and liberal educational assumptions. Drama education adopts experiential learning approaches where the learning outcomes are tacit within learning experiences. Reflective activities are built into learning to help students turn implicit meaning-making into explicit knowledge. The value of student evaluation is similarly stressed by student voice research advocates, who see it as a useful way for enhancing engagement in learning. They believe that students take part in an active discourse as they share stories about their learning journeys. As a result, students develop 'a sense of authorship over their own views as they begin to 
examine views that were previously implicit and taken for granted' (O'Loughlin 1995). Smyth (2006) suggests that discussing with students what has been learned is an authentic and learner-centered mode of self-assessment. Furthermore, as views are shared collectively, students are able to respond to each others' thoughts, feelings and needs. Such sharing nurtures a self-initiated, collaborative learning culture which is also essential to the pedagogy of drama. It takes student voices as 'honoured voices' (Oldfather \& Dahl 1994, 143) that enhance intrinsic motivation and provide a valuable classroom resource - one encompassing Dewey's (1980 [1899]) vision of a transformed recitation $^{1}$

... where experiences and ideas are exchanged and subjected to criticism, where misconceptions are corrected, and new lines of thought and inquiry are set up. (p.34)

Another common ground of drama education and student voice studies lies in the belief in more democratic and dialogic pedagogies. When student voices are valued, and when students are regarded as capable co-participants in educational processes, the power relation in the classroom is shifted to one that is more liberal in nature. Innes, Moss, \& Smigiel (2001) assert that the restoration of teacher-student dialogue through listening to student voices echoes the critical pedagogical epistemology in drama education.

Paulo Freire's view on critical pedagogy addresses a concern over issues of power and oppression. In liberating students from their silenced positions, educators take part in a radical transformation and democratization within the context of schools, and subsequently the society at large (Shor 1993). Opening up student-teacher dialogues defines an educational process

...not as the one-way transfer of knowledge from teacher to students in preparation for performance on a standardized test but rather as a mutually informing, dynamic, human relationship within which knowledge and understanding are co-produced by teachers and students, where teachers [...] and students learn to resist the imposition of oppressive, disempowering, and commonly accepted educational practices.' (Cook-Sather 2006a, 346)

Cook-Sather (2006a) asserts that such a commitment is not based on unreflective acceptance of student perspectives, but an informed and reflective process on the teachers' part.

A third common ground between student voice research and drama education is that both call for transformations in teaching practice. Listening to student voice allows teachers to see learning from the students' perspectives and collect learning evidence of a different order. Good drama educators are able to act as receptive artists capable of going beyond

\footnotetext{
${ }^{1}$ The notion of "transformed recitation" is positioned in opposition to "traditional recitation" in which individual students respond to teachers' questions for the purpose of demonstrating what they have memorized from textbooks in a competition for teachers' rewards.
} 
surface realities of classroom interactions. A similar quality has been valued by advocates of student voice research:

The aim in teacher research is [...] for the teacher to attain the eyes of the stranger or artist, for it is art that teaches the sensitivity of being attentive to significances that normally remain uncelebrated. (Rudduck \& Flutter 2004, 142)

Scholars have regarded the capacity for listening to student voices an important aspect in teachers' professional development (Cook-Sather 2006a, 2007; Flutter 2007). It is also regarded as a helpful means to improve education in school reforms (Flutter \& Rudduck 2004; Rudduck, Chaplain, \& Wallace 1996; Rudduck \& Flutter 2004; Smyth 2006; Thiessen 2006). Similarly, drama education has been gaining recognition as a reform initiative that usefully addresses the call for more heuristic and creative approaches to teaching.

These similarities give a solid ground for the inclusion of student voice in drama education studies, which researchers have often adopted in qualitative case studies of various kinds. This research follows the footsteps of a previous study by Innes, Moss \& Smigiel (2001) and chooses to rely entirely on students' own words as the source of data. Seeing the growth of drama education praxis and the emergence of related research in Hong Kong, it is important to stress the value of student consultation as we evaluate the effectiveness of drama initiatives. This is an area yet to be further developed in educational research in Hong Kong, which tends to value experts' voices over the learners'.

We listen to outside experts to inform us, and, consequently, we overlook the treasure in our very own backyards: our students. Student perceptions are valuable to our practice because they are authentic sources; they personally experience our classrooms firsthand. (SooHoo 1993, 386)

\section{Context of the study}

This project took place in a primary boy's school in Hong Kong; the attempt was to introduce drama education to enhance students' learning in Chinese Language and General Studies - two core subjects in the primary curriculum alongside English Language and Mathematics. The school allocated three double-lessons (60 minutes) from each of the two subjects for implementing a drama programme at each grade level. A 6session Process Drama unit was designed for each class addressing learning objectives of both school subjects. (The Primary One unit was an exception; it contained two shorter Process Dramas).

A cross-subject integration approach was adopted. The Hong Kong Education Bureau sees General Studies as essentially cross-curricular in nature, and supports schools to 
adopt integrated modes of teaching to enable students to explore knowledge and gain experience in a more coherent manner (Curriculum Development Council 2002). Meanwhile, in the Chinese Language key learning area, integrated and cross-curricular links with other school subjects is also laid down in the curriculum guide as an effective means to enhance learning efficacy (Curriculum Development Council 2004).

The school in this study opted for a focus on cultural, moral and affective development in the project, as it sees drama's strength in approaching learning and teaching in this aspect. Such a focus also provided a useful premise for the integrated approach, as moral and affective development are shared learning outcomes in both Chinese Language and General Studies. This arrangement supports the government's advocacy for a more balanced curriculum of knowledge, generic skills, and values and attitudes (Curriculum Development Council 2002, 2004), as well as more holistic language learning that stresses students' affective development:

Language education should embody the human nature of language...Language is a vehicle for thinking and addressing our culture. The purpose of Chinese language education is to enhance students' language capacity, but at the same time it should be balanced with the fostering of students' moral and cultural perspectives.

(Curriculum Development Council 2002, 5) (quote translated from Chinese)

The drama teachers designed the drama units in collaboration with the classroom teachers. Co-planning meetings were attended by all the drama teachers, the panel heads of both school subjects, and all the school teachers teaching the two subjects. These meetings helped the team ensure that the teaching objectives of the drama units were in accordance with the school's syllabus. Related themes from textbook chapters were selected by the school teachers, and the drama teachers worked on them to formulate the content of the drama units. The plans were then presented to the school teachers for comments, and were further revised before implementation. (See Table 2 for the details of the units.)

All classes from Primary 1 to 4 (23 classes in total) participated in the drama units. It was the first time the students were introduced to drama as a medium of learning. The drama units were led by the drama teachers from Hong Kong Art School. The school teachers participated in the lessons to help facilitate the classes and to observe students' learning. Three or four students from each class were chosen as targets of focused observation, comprising high, middle \& low achievers with regard to the specific learning outcomes of respective units. Students were asked to complete a journal entry after each lesson, and an end-of-unit language assessment task (written or oral) was designed for each unit.

\section{Methodology}

We conducted focus group interviews for all grade levels upon completion of each drama unit to find out students' views towards their learning experiences. A total of 68 students 
were selected across all grade levels, with 2 to 4 representatives from each class (Table 1). Where possible, the students selected as the targets for classroom observation were invited. Other participants at the focus group interviews were selected by the school teachers if there was observable changes during their participation in the drama units.

\begin{tabular}{|l|l|}
\hline Grade Level & Number of Students \\
\hline Primary 1 (6 classes) & 18 \\
\hline Primary 2 (5 classes) & 11 \\
\hline Primary 3 (6 classes) & 18 \\
\hline Primary 4 (6 classes) & 21 \\
\hline Total & $\mathbf{6 8}$ \\
\hline
\end{tabular}

Table 1: Distribution of students participating in focus group interviews

The focus group interviews were conducted by the drama teachers. It was arranged in a way that the teacher of a particular class would not interview his/her own students and the school teachers did not attend the interviews. These arrangements aimed at minimizing the 'teachers' effect' in the interviews.

The interviews were video-recorded and transcribed for analysis. The analysis was done by the researcher in consultation with the school teachers and the other drama teachers in the programme. Key ideas shared in the focus group interviews were discussed amongst the team members to shed light on their possible implications.

The interviews were all conducted in Cantonese, the students' mother tongue. The transcripts quoted in this article are the author's translations.

\section{What the students said about the drama units}

\section{It didn't help me learn new words}

When asked what they felt about the connection between the drama units and their learning in the two school subjects, the students gave an almost unanimous response saying that a stronger link was found with General Studies than Chinese Language. A typical answer was:

I think [the drama unit] was helpful to my studies in General Studies. The knowledge we came across was essentially general knowledge. However, I don't think it was helpful to my studies in Chinese. It was not language teaching. No new words were taught. (Primary 3 )

The students' view on language learning was limited to the acquisition of new vocabulary and learning to read or write. The small number of students who said that the drama units were helpful to their language learning showed similarly narrow views:

We had to write sentences in the worksheets. So I think it was a bit helpful to my study in Chinese Language. (Primary 3) 
Since we had to read the questions in the worksheets, we learned some new vocabulary. (Primary 3 )

Many of us would choose to write in the drama journals rather than draw pictures. So it helped us learn Chinese. (Primary 4)

Such views on the nature of language learning are worth noting. Apparently the students held a rather narrow conception of language education, where the learning of prescribed vocabulary is of paramount concern. Holding such a view, they found the drama work of little relevance to the language curriculum.

Drama educators argue for the value of drama in providing authentic contexts for language use. The findings of this study reveal that even when this happens, students don't necessarily see it as strongly connected to their subject learning:

At the end of the unit, we had to do a piece of writing on the theme of 'water shortage'. If I had not attended the drama lessons, my writing would have lost its authenticity... So I think the drama unit and Chinese Language are barely related to each other. (Primary 4) (author's italics)

Such a narrow view of language learning also precluded most students in the study from considering enhanced speaking skills as a learning outcome of the Chinese Language subject.

\section{I felt like speaking as a 'big muscular guy'!}

A considerable number of the students interviewed said that the drama units helped them become more confident speakers. However, only a few older students related this to the subject of Chinese Language:

The drama lessons were useful to Chinese Language as it trained our speaking skills... We used different tones in playing different characters. (Primary 4)

I think it had helped my Chinese Language studies. I seldom spoke.

But in the drama lessons, I spoke more actively. (Primary 4)

Though not referred to as a Chinese subject skill, the enhancement of speaking skills and expression stood out as a recurring theme in the focus group interviews. Most of the students, regardless of grade level, related this to the more active and relaxed atmosphere in the drama lessons.

I became bolder when I spoke. When the activities were of so much fun, we naturally became bolder! I felt like I was speaking as a 'big muscular guy'! (Primary 2) 
In a few occasions, students related the enhancement of speaking skills to the fictional context of the drama works. For instance, referring to the drama unit The Disappearance of Rice (Table 2), a student recalled:

Student: That time, I was in role as a protester who fought for farmers' rights. I had to argue with that guy... Usually we wouldn't speak to the teacher like that.

Interviewer: You had a debate with the government official played by the teacher, and so you became bolder?

Student: Yes!

(Primary 3)

However, most of the students did not explain their learning this way. Only a small number of them addressed the fictional context of the drama. Most of them were more ready to attribute their language enhancement to what O'Toole (1992) refers to as 'the context of the medium' - the pedagogical setting where a more playful and active style of learning fostered their confidence in speaking.

Yet, this playful atmosphere of learning does not always help the students see the link between drama and their school subjects.

\section{We were merely playing around in class!}

Some of the students explained the relationship of drama with their school subjects in terms of how the two subjects were usually delivered to them. A Primary One student pointed out a resemblance between the teaching method of her drama teacher and that of his teacher of General Studies:

Like our teacher in General Studies, my drama teacher always asks us questions and encourages us to work out the answers ourselves. (Primary 1)

The different pedagogical approaches previously adopted by the subject teachers seemed to bear an impact on the students' perception of the links between drama and the school subjects. General Studies is more like drama as a more interactive, inquiry approach to teaching is often adopted. Chinese Language, however, is more serious and rigid in the students' eyes.

Student: I think the drama unit has been helpful to General Studies, as I have learned new things. Yet as we are merely playing around in the lessons, I don't think it helps my Chinese learning.

Interviewer: But why do you think it is helpful to General Studies, when you are also just playing around?

Student: (paused for a thought) Because we have learned something new about the farmers. 
This final remark brings to light a key factor in the students' perception of a link between the drama unit and General Studies - one related to how they view knowledge.

\section{It gets me to experience something I didn't know before}

The majority of the students in this study found a positive link between General Studies and the drama units. For them, General Studies was about acquisition of knowledge. When the drama units could provide them with new knowledge, a close connection between drama and General Studies occurred.

Most students said that the drama units increased their motivation in acquiring knowledge as a result of the vivid method of learning. Some older students explained how deeper knowledge was gained through their dramatic encounters.

Student: I used to know that the farmers' lives are harsh. However, taking part in the drama lessons, I got to feel that the hardship was much bigger than what I imagined.

Interviewer: Which part of the drama made you feel so?

Student: I saw that the food they ate were different from ours. They ate very simple food.

(Primary 3, on The Disappearance of Rice, Table 2)

It is worth mentioning that the food seen by the student was actually what he imagined as he was making a freeze frame of farmers at the dining table. In other words, the student generated an authentic feeling from his imagination, which he referred to as 'new' knowledge - a felt type of knowledge as opposed to textbook knowledge.

A few Primary Four students clearly articulated the difference between knowledge in textbooks and the embodied knowledge they obtained from drama.

Student: [The drama unit] helps me in General Studies. It is related to a chapter in our textbook. It was about the history of Hong Kong and how people lived in housing quarters. So it was useful.

Interviewer: Since the topic has already been explained in the textbook, does it make any difference doing the drama or not?

Student: It does! The textbook only covered the topic briefly. But in the drama, we experienced it. So we understood more.

Interviewer: Could you give me an example?

Student: $\quad$ Say... we have never experienced water shortage. Taking part in the drama, we experienced the hardship during the times of water shortage. I had to get up at 3 or 4 o'clock in the morning to get water. Usually I don't get up until 8 
o'clock! We had to queue up to get water, and I was in the queue for a few hours!

(Primary 4, on Dwelling in Public Housing, Table 2)

Interviewer: Your textbook covers many aspects of people's life in the 1970s. In the drama unit, we only covered the topic of water shortage. Why do you think you have learned more?

Student: In the drama lesson, we took part in activities that made us understand those things more deeply. It was more effective than reading the words from the textbook.

(Primary 4 on Dwelling in Public Housing, Table 2)

\section{Cultural, moral and affective development}

Cultural, moral and affective development was chosen as the focus in the design of the drama units, as it was an obvious link between the two school subjects for cross-subject integration. Yet the students seemed to see a limited connection between moral and values education and their school subjects.

However, the fact that they didn't see the connection does not mean that they did not find the drama units helpful in developing moral and cultural values. On the contrary, the majority of them gave rich descriptions of how the drama work brought them to reflect on various moral values, as seen in the way they responded to the following questions which did not make explicit links to the two school subjects:

Which part(s) of the unit was/were most impressive to you?

What have you learned from the drama unit?

The students recollected moments in the drama work when they could strongly identify with the roles they took. For instance, a Primary One student, having taken the role of a piece of toy owned by an abusive young boy, said, 'I felt as if the toy also had a life.' He told us that such a feeling made him reflect on the way he should treat his belongings.

A group of Primary Two students also discussed their deep engagement with the role of the mother of Yue Fei, the ancient hero:

Student A: I used to be not very kind to my mother. Having done this story, I realized that filial piety is good.

Interviewer: How did you learn that?

Student A: After playing the role of the mother, I understood how mothers love their children.

Student B: I was pretty sad when I played the mother because my son might die in the war.

(Primary 2, on Yue Fei, Table 2) 
Other Primary Two students also said that they gave deeper thoughts to big human themes related to filial piety, loyalty and bravery through the eyes of Yue Fei, as he was faced with huge dilemmas. They recalled their struggling thoughts as they stood along a Conscience Alley deciding on whether Yue Fei should part with his beloved mother to become a general.

If he left his mother, he might never see her again. He might die in the war. (Primary 2)

But if he did not join the army, his country would be at stake. His mother might end up dying in the war as well. (Primary 2)

His mother loved him, but she also wanted him to serve the country loyally. (Primary 2)

These reflections were a result of the multiple perspectives made available by the framing of the drama. These kinds of impacts were even more noticeable in the Primary Three drama unit, The Disappearance of Rice (Table 2). Students encountered the different roles of farmers in a developing country, merchants, government officials, NGO demonstrators and children in developed countries while they explored social issues around farmers' lives. During the focus group interviews, the depth of reflections from the Primary Three students was distinctly different from participants in other grade levels, revealing considerations of big themes like oppression, equity and justice:

Student A: Farmers are the same as any other human beings. People should not look down on them.

Student B: Human beings should not be classified. Why should people see the government officials as superior to the others?

Student C: The children in the drama, those who came from the developed country, discriminated against farmers. I think that was totally unnecessary.

Student D: ... we are all human beings, regardless of which country we come from. Farmers are human beings as well.

Student B: Every person has one's own ability and achievements...

Student D: We shouldn't look down on the farmers...

Student E: We shouldn't look down on any people, especially those in poor conditions.

(Primary 3)

The impact of the drama also extended to students' understanding of real-life situations, giving rise to more multi-dimensional considerations of the demonstrations held against the World Trade Organisation in Hong Kong, 2005.

Interviewer: Has this unit influenced your views on the WTO demonstrations? 
Student A: If I had not taken part in this drama, I would never have understood why the Korean farmers have to go on protest.

Student B: If I had not taken part in this unit, I would have thought that the police were absolutely right [in dispersing the demonstrators]. Now I still think that the police were right, but I think the WTO had some wrong-doings.

(Primary 3)

\begin{abstract}
Abundant as these narratives are, when the students were asked a different question later in the interviews - one about whether they found the drama units helpful in their learning in Chinese Language and General Studies - such learning experiences on moral, civic and values education were scarcely quoted. The students seemed to see a weak link between the development of values and attitudes and the curriculum.
\end{abstract}

\title{
Discussion
}

\section{On school reform and curriculum development}

The students' views in this study provided insights into curriculum integration and the use of drama as a means for such integration. These views, embodying the students' dayto-day educational experiences, served as a helpful mirror for us to examine the effectiveness of curriculum reforms.

Recent educational reforms place much emphasis on holistic, integrated and all-round learning experiences that go beyond mere acquisition of factual knowledge. For years, the Hong Kong Government has been advocating a more balanced curriculum perspective that gives equal standing to knowledge, generic skills, as well as values and attitudes. The students' views in this case study indicated the gap between the rhetoric and what happens in the everyday classroom. The students apparently did not perceive the development of values and attitudes as a subject learning outcome that was as important as knowledge acquisition. In the case of Chinese Language learning, the kind of knowledge that mattered to the students was founded on a narrow notion of language education.

The Chinese Language curriculum in Hong Kong has undergone a number of major changes as it evolves with the changing socio-economic circumstances. With a move from labour-intensive manufacturing to high-technology service industries in society, the new Chinese Language curriculum seeks to incorporate the added perspectives of enhancing students' moral, intellectual, social development and socio-cultural awareness (Adamson \& AuYeung Lai 1997). Zhu \& Yung (2008) point out that historically the Chinese language teaching sector has paid little attention to students' cultural literacy and affective development, and call for more attention towards such issues in teacher development to catch up with new curriculum demands.

Meanwhile, the new General Studies curriculum launched in recent years stresses students' active role in the construction of their own learning by encouraging an inquiry- 
based learning approach. The students in this study rightly pointed out the links between this newly advocated pedagogy and drama education. Yet the development of social and cultural values was seen as having little relevance to the school subject despite the claims in government curriculum documents.

The findings of this study inspire us to continue the challenges of introducing drama pedagogy in the school curriculum and as a subject integration approach in Hong Kong. The students' views confirmed what Shu (2007) sees as a limiting factor in implementing drama initiatives:

Contextual learning with dramatic exploration might not always facilitate the teaching of hard facts and skills, leading to the usual comments of 'not effective enough' in achieving learning objectives in respective subjects. (p. 300)

While Shu is mainly referring to the mindsets of teachers and school decision makers, this study reminds us that drama also challenges students who have been subject to highly traditional classroom approaches to change their views towards learning. The findings add to the growing literature (Liu 2002; Kao, 1992) on the benefits and challenges of introducing drama to Chinese classrooms in which more traditional teaching methods and an exam-driven culture still prevail.

\section{The author's journey in listening to student voices}

The outcomes of this study support the notion that students are capable of providing valid input into the evaluation of education. The views shared by students in this study not only help us understand how they perceive the nature of dramatic learning, but also reveal their common beliefs about what the learning of school subjects encompasses, as well as their understanding of the pedagogical approaches they have previously encountered.

By listening to what the students said, I have also gained deeper understandings of young people's world views. An example was seen in a conversation with one group of Primary Four students, who enabled me to realize the misunderstandings they held towards people's life in the 1970s:

Student A: I used to think that Hong Kong people were rich in the past. Our lives are rich nowadays, so I thought people wouldn't be too poor in the past. After this drama unit, I realized that it was not the case.

Student B: I heard that Hong Kong had been occupied by England and Japan before. I thought those rich countries would have brought Western cultures to Hong Kong. So I thought Hong Kong people were rich then.

Student C: I used to think that people in the past were rich because they could afford to raise many children. 
What appears to be a simple lack of historical knowledge on the surface illustrates how young people understand the world differently from adults. With their limited life experiences, children try to make sense of life in the past via deductions, and these deductions are inevitably based on their present life experiences (and all are quite logical in this sense!) As adults who were brought up in an entirely different socio-economic environment, we might easily overlook how young people perceive the world, and why certain things are difficult for them to comprehend. Listening to student voices has provided me with a rich resource for my professional development.

The journey of this research has been a rich and valuable one, but at the same time posed further questions. One challenge to student voice studies is that researchers often only hear from the more articulate and confident learners (Flutter 2007). In the course of this study, despite our efforts to diversify the interviewees as much as possible in terms of their learning abilities, when I analyzed the data, I found that most of the richer data or narratives came from the older students who were able to articulate their thoughts and give more comprehensive descriptions of their learning experiences. In one of the interviews, a boy with learning difficulties was involved. He basically said nothing no matter how hard his peers and I tried to encourage him. We successfully included him in the evaluation process, but failed to include his voice in any of the findings. This brings me to re-consider the use of focus group interviews with students of different learning styles and abilities. As drama educators who advocate for diverse learning strategies, it is useful for us to examine more diverse, alternative, non-verbal means of eliciting student voices so that the minority are not silenced, and the inclusion of a 'plurality of voices' (Fielding 2004) might be achieved.

Which students are representing the student voice of their school? And in the context of reform, can these students who are best served by the current set-up of their school possibly serve the interests of students who are least well-served? (Silva quoted in Fielding 2004, 302)

\section{Acknowledgements}

The author would like to express her deepest gratitude to Chow Kit-mui Winnie, Liu Puifong, Kwong Wing-kin Kenny, Lam Yin Krissy and Suen Kwan-ying Rita for their collaboration in the project and the invaluable insights shared on the research findings. She would also like to thank Ms Monique Tang for helping to proofread the English text of this article.

\section{Notes on Contributor}

Chan Yuk-lan Phoebe is Lecturer/Programme Coordinator (Drama Education) at the Hong Kong Art School, where she convenes a Master of Drama Education Programme co-organised with Griffith University, Australia. She has a Master's Degree in Drama in Education from the University of Central England, and is currently undertaking her $\mathrm{PhD}$ study with Griffith University. For more than ten years, she has worked with theatre 
companies, schools, community groups and Oxfam Hong Kong in stage performance, applied theatre and Theatre-in-Education, teacher development in the use of drama as pedagogy, research projects, as well as editing, translating and authoring publications.

\section{References}

Adamson, B., \& AuYeung Lai, W. 1997. Language and the curriculum in Hong Kong: Dilemmas of Triglossia. Comparative Education, 33(2): 233-246.

Cook-Sather, A. 2006a. 'Change based on what students say': Preparing teachers for a paradoxical model of leadership. International Journal of Leadership in Education, 9(4): 345-358.

Cook-Sather, A. 2006b. Sound, presence, and power: 'Student voice' in educational research and reform. Curriculum Inquiry, 36(4): 359-390.

Cook-Sather, A. 2007. What would happen if we treated students as those with opinions that matter? The benefits to principals and teachers of supporting youth engagement. NASSP Bulletin, 91(4): 343-362.

Curriculum Development Council. 2002. Curriculum Guide for General Studies (Primary 1-6): Hong Kong Government.

Curriculum Development Council. 2004. Curriculum Guide for Chinese Language (Primary 1 to 6): Hong Kong Education and Manpower Bureau. (Chinese reference)

Dewey, J. 1980 [1899]. The school and society. Carbondale: Southern Illinois University Press.

Fielding, M. 2004. Transformative approaches to student voice: Theoretical underpinnings, recalcitrant realities. British Educational Research Journal, 30(2): 295-311.

Flutter, J. 2007. Teacher development and pupil voice. The Curriculum Journal, 18(3): 343-354.

Flutter, J., \& Rudduck, J. 2004. Consulting pupils: What's in it for schools? London: RoutledgeFalmer.

Innes, M., Moss, T., \& Smigiel, H. 2001. What do the children say? The importance of student voice. Research in Drama Education, 6(2): 207-221.

Kao, S. M. 1994. Classroom interaction in a drama-oriented English conversation class of first year college students in Taiwan: A teacher-research study. Unpublished doctoral dissertation, the Ohio State University, Columbus.

Liu, J. 2002. Process drama in second- or foreign-language classrooms. In Body and language. Intercultural learning through drama, ed. G. Brauer, 51-70. Westport: Alblex.

O'Loughlin, M. 1995. Daring the imagination: Unlocking voices of dissent and possibility in teaching. Theory into Practice, 34(2): 107-116.

O'Toole, J. 1992. The process of drama: Negotiating art and meaning. London: Routledge.

Oldfather, P. 1995. Songs 'Come Back Most to Them': Students' experiences as researchers. Theory Into Practice, 34(2): 131-137. 
Oldfather, P., \& Dahl, K. 1994. Toward a social constructivist reconceptualization of intrinsic motivation for literacy learning. Journal of Reading Behaviour, 26: 139158.

Rudduck, J., Chaplain, R., \& Wallace, G. (Eds.). 1996. School improvement: What can pupils tell us? London: David Fulton Publishers.

Rudduck, J., \& Flutter, J. 2000. Pupil participation and pupil perspective: 'Carving a new order of experience'. Cambridge Journal of Education, 30(1): 75-89.

Rudduck, J., \& Flutter, J. 2004. How to improve your school: Giving pupils a voice. London: Continuum.

Shor, I. 1993. Education is politics. In Paulo Freire: A critical encounter, ed. P. McLaren \& P. Leonard, 25-35. London: Routledge.

Shu, C. Y. J. 2007. Drama-in-Education versus Drama Education as Pragmatism. In Risks \& Opportunities: The Tension in Hong Kong Drama Education Development, ed. C. Y. J. Shu \& Y. P. E. Wong, 298-303. Hong Kong Drama/Theatre and Education Forum.

Smyth, J. 2006. When students have power: Student engagement, student voice, and the possibilities for school reform around 'dropping out' of school. International Journal of Leadership in Education, 9(4): 285-298.

SooHoo, S. 1993. Students as partners in research and restructuring school. The Educational Forum, 57: 386-392.

Thiessen, D. 2006. Student knowledge, engagement, and voice in educational reform. Curriculum Inquiry, 36(4): 345-358.

Zhu, Z. H., \& Yung, H. H. Implementing the Revised Chinese Curriculum, Further Enhancing Chinese Teachers' Quality. http://cd.edb.gov.hk/chi/news/doc_9/45.pdf. (retrieved on 8 July 2008). (Chinese reference) 
Table 2: The Drama Units

\begin{tabular}{|c|c|c|}
\hline Grade Level & Name of Unit \& the Dramatic Context & Key Learning Outcomes \\
\hline Primary 1 & $\begin{array}{l}\text { Lok Lok's Room } \\
\text { Lok Lok is moving house. Students are } \\
\text { put into role as his belongings to tell him } \\
\text { how they feel about the way he treats } \\
\text { them, and to suggest where they shall go } \\
\text { upon the move. }\end{array}$ & $\begin{array}{l}\text { Students engage in the feelings of Lok Lok's belongings and reflect on how they treat their own } \\
\text { belongings. Also, they are supported to make more considered decisions on how to deal with old } \\
\text { stuff. } \\
\text { General Studies Link: A textbook chapter named 'Household Facilities', on developing children's } \\
\text { understanding of the functions of different household facilities. }\end{array}$ \\
\hline Primary 1 & $\begin{array}{l}\text { Mr Gift } \\
\text { Students help Old Mr Gift to give out } \\
\text { gifts - but they are tested by Mr Gift on } \\
\text { their understandings of the meanings of } \\
\text { gift-giving. }\end{array}$ & $\begin{array}{l}\text { Students try to think about others' needs, and explore non-materialistic means of expressing } \\
\text { gratitude. } \\
\text { Chinese Language Link: A textbook chapter named 'Borrowing Birthday' - on the meanings of } \\
\text { gift-giving. }\end{array}$ \\
\hline Primary 2 & $\begin{array}{l}\text { Yue Fei } \\
\text { Students are enroled as on-line game } \\
\text { designers to research on the story of the } \\
\text { ancient hero, Yue Fei, and to develop } \\
\text { educational software for children. }\end{array}$ & $\begin{array}{l}\text { By exploring Yue Fei's stories, students are encouraged to adopt higher ordered thinking by } \\
\text { considering the various dilemmas Yue Fei faced, and reflect on the values of filial piety and } \\
\text { loyalty. } \\
\text { Chinese Language Link: a textbook chapter on the story of Yue Fei } \\
\text { General Studies Link: a textbook chapter on 'Famous Chinese People in History' }\end{array}$ \\
\hline Primary 3 & $\begin{array}{l}\text { The Disappearance of Rice } \\
\text { Students are framed in role as researchers } \\
\text { in the future, who travel back in time to } \\
\text { investigate why farmers no longer grow } \\
\text { rice. }\end{array}$ & $\begin{array}{l}\text { Students experience the hardship that farmers face in their manual work, and the problems they } \\
\text { face socially and economically, thus developing a concern for social minority groups, and } \\
\text { encouraging them to reconsider farmers' contribution to the society as well as people's attitude } \\
\text { towards food producers. } \\
\text { Chinese Language Link: two textbook chapters: 'Having Buffet' and a poem named 'Empathizing } \\
\text { with Farmers' } \\
\text { General Studies Link: a textbook chapter on 'Abundance in Clothing and Food' }\end{array}$ \\
\hline Primary 4 & $\begin{array}{l}\text { Dwelling in Public Housing } \\
\text { Students are engaged in role as dwellers } \\
\text { of public housings in } 1970 \text { s, who lived } \\
\text { under water shortage and had to work out } \\
\text { ways of dealing with the problem } \\
\text { cooperatively. }\end{array}$ & $\begin{array}{l}\text { Students experience and understand life in the } 1970 \text { s when people had to share scarce social } \\
\text { resources, thus considering issues about neighbourhood and the relationship between the individual } \\
\text { and the community. They are also engaged in research activities in which they have to elicit } \\
\text { personal stories from their senior family members on life in the past. } \\
\text { Chinese Language Link: a textbook chapter called 'Transportation in the Past' } \\
\text { General Studies Link: a textbook chapter on 'People's Lives in the Past' }\end{array}$ \\
\hline
\end{tabular}


